\title{
Marriage, Divorce and Interstate Risk Sharing
}

by

Martin Halla, Johann Scharler ${ }^{*}$ )

Working Paper No. 0816

October 2008

Johannes Kepler University of Linz Department of Economics Altenberger Strasse 69 A-4040 Linz - Auhof, Austria www.econ.jku.at

martin.halla@jku.at johann.scharler@jku phone +43 (0)70 $2468-8219$ phone $+43(0) 702468-8360$ 


\title{
Marriage, Divorce and Interstate Risk Sharing*
}

\author{
Martin HaLla \\ University of Linz \& IZA
}

\author{
JOHANN SCHARLER \\ University of Linz
}

October 2, 2008

\begin{abstract}
In this paper we study the importance of marriage for interstate risk sharing. We find that US states in which married couples account for a higher share of the population are less exposed to state-specific output shocks. Thus, marriages do not just improve the allocation of risk at the individual level, but also have implications for the allocation of risk at the more aggregated state-level. Quantitatively, the impact of marriage on interstate risk sharing varies over divorce regimes.
\end{abstract}

JEL Classification: J12, E21, K36, G21.

Keywords: Risk sharing, marriage, divorce, family law.

${ }^{*}$ Corresponding author: Johann Scharler, University of Linz, Department of Economics, Altenbergerstr. 69, 4040 Linz, Austria. Phone: +43 702468 8360, Fax: +4370 2468 9679, email: johann.scharler@jku.at. For helpful discussion and comments we would to thank Johann K. Brunner, Corne van Walbeek and Rudolf Winter-Ebmer. The usual disclaimer applies. 


\section{Introduction}

Modern economies provide several formal and informal mechanisms through which the exposure to risks at the individual, regional and country level can be reduced (see Cochrane, 1991, for a detailed discussion). Financial markets, for instance, allow to insure against risks by holding diversified portfolios. States introduce fiscal tax and transfer programs to provide risk sharing. Labor contracts may also implicitly contain insurance elements (Azariadis, 1975). Thus, risk sharing may in principle occur through various formal and informal channels.

Family economics emphasizes the idea that marriage provides risk sharing among a couple (Weiss, 1993). More specifically, voluntary transfers between spouses help to smooth out fluctuations in individual income streams. A large body of empirical studies using micro data shows that risk sharing indeed occurs within marriages (see e.g. Rosenzweig and Wolpin, 1985; Rosenzweig, 1988; Rosenzweig and Stark, 1989; Rosenzweig and Wolpin, 1994).

In this paper we argue that marriages also improve the sharing of risks at more aggregated levels. Consider for instance an adverse, region-specific shock, i. e., a shock that hits the population of a certain region equally. The consumption risks associated with such a shock cannot be diversified within the region, but only across regions. This type of inter-region risk sharing may occur, for instance, via borrowing from a bank. So essentially risk is to some degree shared with a bank in the region. The bank then diversifies these risks across regions. In fact, Demyanyk, Ostergaard, and Sørensen (2007) show that risk sharing across US federal states occurs to a non-negligible extent indirectly through banks. Since there is convincing evidence that being married improves the availability of bank credit (Ladd, 1982; Elliehausen and Lawrence, 1990; Munnell, Tootell, Browne, and McEneaney, 1996), marriage should foster this type of risk sharing. ${ }^{1}$ That is, marriage may not only help to pool individual risks, but may also reduce the exposure to region-specific shocks. It follows that marriages may give rise to additional welfare gains beyond those associated with the pooling of individual risks.

The purpose of this paper is to explore empirically the influence of trends in marriage and divorce on risk sharing across US federal states. Thus, we combine two important strands of the economic literature studying risk sharing. The first strand quantifies the amount of risk sharing across regions. The second strand emphasizes risk sharing implications of marriage at an individual level. The main contribution of our paper is fruitfully bringing together these two

\footnotetext{
${ }^{1}$ Banks may prefer married applicants since they share all sorts of risk with their spouse and consequently default risk should be lower compared to their single counterparts. In this sense, marital status is an effective screening device which can be observed with low cost.
} 
strands of literature that have so far remained largely separate. In fact, this is the first study providing empirical evidence that a more efficient allocation of risk at the individual level has also implications for the allocation of risk at the more aggregated level. Moreover, our findings add to each strand in further substantive dimensions.

Based on the framework proposed by Asdrubali, Sørensen, and Yosha (1996), we find that states with higher shares of married population in the total adult state population are indeed less exposed to state-specific output shocks. This result is consistent with our main hypothesis that marriages do not just improve the allocation of risk at the individual level, but also at the state-level. In addition, by showing that the risk sharing benefits associated with marriages add up and can be detected in aggregated state-level data, our paper complements the existing research on the role of marriage for risk sharing employing micro data.

The effect of marriages on the availability of bank loans and thus on interstate risk sharing may be influenced by the degree to which risks are shared within marriages. It is often conjectured that a high risk of divorce is associated with a low level of (financial) co-operation during marriage (Anderberg, 2007). Consequently, the likelihood of divorce should decrease in the cost of divorce and in the couples' match quality. In order to observe an exogenous variation in the divorce propensity we exploit the different timing of divorce law reforms across US states. In particular, we explore the move from mutual consent to unilateral divorce laws (see Clark, 1999) and changes in the laws regarding the division of matrimonial property. These divorce law reforms affected the incentive to invest in marriage-specific capital (Stevenson, 2007) and the selection into marriage (Rasul, 2006; Matouschek and Rasul, 2008), i. e. the match quality of the average couple. Our results show that the positive effect of marriages on risk sharing is lower in states allowing for unilateral divorce. This supports the idea that risk sharing under incomplete contracts increases in the cost of default (Ligon, Thomas, and Worrall, 2002).

Concerning the division of matrimonial property, we analyze the move from common property to an equitable property division. This reform makes it easier for banks to assess the net worth of creditors after a potential divorce, and therefore banks should prefer to lend to married couples under equitable property division. Accordingly, we find that a divorce regime with more equitable division of property indeed improves the effect of marriage on interstate risk sharing.

In addition, our results indicate that the effect of marriage on interstate risk sharing differs across periods of economic down and upturns. We find some evidence suggesting that marriages improve risk sharing when it is most needed, namely during downturns. More specifically, the higher the share of marriages, the lower the exposure to state-specific risk during periods when 
the growth rate of gross state product is below average.

The remainder of the paper is structured as follows: In Section 2 we discuss our main hypothesis that marriages increase intra- as well as interstate risk sharing. Section 3 outlines the empirical implementation, while Section 4 describes our data set. In Section 5 we present our estimation results. Finally, in Section 6 we conclude the paper.

\section{Marriage and Risk Sharing within and across States}

In this section we motivate our hypothesis that marriages may be related to the degree to which consumption risks can be pooled across states.

Becker $(1973,1974)$ introduced the idea that marriage is a partnership for the purpose of joint production and joint consumption. The economic gains from marriage are given by specialization, economies of scale, sharing of non-rival goods and, the concern of our research, risk sharing. For concreteness, consider a married couple where each spouse receives an income each period and their incomes are not perfectly correlated. If individual incomes fluctuate over time the spouse can smooth their consumption by engaging in risk-sharing through voluntary transfers.

This type of risk sharing has been emphasized as particularly relevant in developing economies where the access to financial markets is limited and formal insurance arrangements are essentially absent. However, as emphasized by Hess (2004) and Chami and Hess (2005), the risk sharing implications of marriages can also explain a non-negligible fraction of the marriage and divorce trends in the US. Thus, even in the US where financial markets are highly developed, risk sharing provided through marriage plays a role. In fact, the institution of marriage may even be superior to conventional insurance markets. Since marriages involve a certain level of trust and information, it may alleviate problems of moral hazard, adverse selection, and deception (Kotlikoff and Spivak, 1981) which are typically associated with insurance markets. Moreover, by providing insurance within marriage, transaction costs may be lower than those associated with formal insurance and financial markets.

Thus, marriages may lead to improved risk sharing among couples and therefore helps to pool individual risks. In this paper, we go one step further and analyze if marriages also help to pool state-specific risks. That is, risks which can only be diversified across states but not within states. We argue that marriages may improve interstate risk sharing by increasing the access to bank credit. While agents can share risks with residents of other states directly by 
exchanging claims on their outputs, they may also share these risks indirectly via banks. ${ }^{2}$ This type of indirect sharing via an intermediary appears to be particularly relevant, since the direct participation of households in financial markets is limited even in the US, see e.g. Korniotis and Kumar (2007).

So, at the intrastate-level, banks share risks with the residents of a state, and at the interstatelevel, banks then diversify these risks across states. This diversification is done either via outof-state borrowing and lending or via the cross-ownership of banks across states. Demyanyk, Ostergaard, and Sørensen (2007) and Hoffmann and Shcherbakova (2007) present evidence showing that banks indeed play a substantial role in the sharing of risks across states in the US.

However, the availability of bank credit is an important prerequisite for this type of risk sharing to work and a substantial literature argues that informational frictions may lead to situations where the access to credit is limited. Thus, agents are likely to face constraints on the market for bank loans which limits the extent of risk sharing within and also across states. Korniotis and Kumar (2007) find that states with greater constraints are more exposed to idiosyncratic risk. Moreover, several studies find that banks discriminate on the basis of marital status (Ladd, 1982; Elliehausen and Lawrence, 1990; Munnell et al., 1996). ${ }^{3}$ It is plausible that these constraints are less binding for married couples, since family incomes may be less volatile due to intra-family risk-sharing. Put differently, expected future family income streams are more predictable than individual income streams. So essentially, marriage may serve as a substitute for collateral. Thus, credit constraints may be less binding for married couples since they can more easily borrow against their expected future incomes. In Table 5 in the Appendix we provide empirical evidence using a cleaned data set from Munnell et al. (1996), provided by Hunter and Walker (1996), on loan applications collected by the Federal Reserve Bank of Boston. Our probit analysis shows that - controlling for many other factors such as income, wealth and credit ratings - being married increases the probability of loan approval by 4.5 percentage points.

Accordingly, we expect that the access to bank credit is more widely spread in states where a higher share of the population is married. Therefore, we expect a higher degree of risk sharing between residents and banks within a given state. And since banks, in turn, are able to diversify a larger fraction of the state-specific risk across states, we also expect to see less exposure to

\footnotetext{
${ }^{2}$ Boot (2000) provides a general discussion of banks in the context of risk sharing.

${ }^{3}$ This discrimination occurs despite the fact that the Equal Credit Opportunity Act was amended in 1976 to ensure that all consumers are given an equal chance to obtain credit. In particular, it is unlawful for any creditor to discriminate against any applicant on the basis of race, religion, national origin, sex, marital status, or age (provided the applicant has the capacity to contract).
} 
state specific shocks in states which are characterized by relatively more married couples.

Of course, risk sharing arrangements are in principle not confined to a married couple. They can certainly apply to any human partnership. For instance, cohabiting couples can also coordinate their activities and share consumption risks. However, empirical evidence shows that cohabiting couples are much less likely than married couples to pool financial resources, are more likely to postulate that each partner is responsible for supporting himself or herself financially and are less likely to agree on the future of their relationship (Blumstein and Schwartz, 1983; Waite, 1995). This uncertainty clearly reduces both investment in the relationship and the ability to pool risks. Moreover, from a legal perspective cohabitation has some but not all of the characteristics of marriage. In particular, married spouses in general face legal restrictions on their relationship that forces them to cooperate. Therefore, it is reasonable that banks prefer a married creditor compared to a cohabitating counterpart.

Note also that, if the thread-point of divorce hangs in the air and the transfers cannot be fully legally enforced the efficient level of transfers is endangered. Therefore, in reality the risk of divorce my prevent couples from (full) risk sharing. Consequently, the amount of risk sharing within marriage and across states depends on the likelihood of divorce. In order to explore the effect of divorce propensity on interstate risk sharing we will exploit exogenous variation in divorce legislation in Section 5.1.

\section{Empirical Implementation}

Our empirical analysis is based on the approach advocated by Asdrubali et al. (1996) to quantify risk sharing among US federal states. Intuitively, this approach reflects the idea that if idiosyncratic risks are perfectly insured, then the growth rates of state consumption and state output should be uncorrelated. More specifically, under complete markets, the necessary conditions for an efficient allocation of risk imply that the intertemporal rates of substitution have to be equalized across the agents in the regions. If we additionally assume that preferences can be represented by constant relative risk aversion utility functions, we obtain that consumption growth rates have to equalize across regions: $\Delta \log c_{i t}=\Delta \log c_{j t}$, for the $i, j=1, \ldots, N$ states, where $c_{i t}$ denotes real per capita consumption in state $i$ at time $t$ and $\Delta$ is the first difference operator. Since this condition holds for any two states, it must also hold with respect to aggregate US consumption denoted by $c_{t}: \Delta \log c_{i t}=\Delta \log c_{t}$.

Hence, state-specific consumption growth is determined only by aggregate US consumption 
growth and not by idiosyncratic risk factors such as state output. Intuitively, the impact of fluctuations in state output is completely diversified away under complete markets. However, if complete insurance is not feasible, then state output may influence state consumption to some extent. To obtain a proxy for state-specific output, we follow Asdrubali et al. (1996) and subtract the growth rate of aggregate US output growth: $\tilde{y}_{i t}=\Delta \log y_{i t}-\Delta \log y_{t}$, where $y_{t}$ is the population weighted average of $y_{i t}$. This transformation eliminates movements in output growth that are common to all states and can therefore not be diversified across states. Thus, we obtain: $\tilde{c}_{i t}=\beta \tilde{y}_{i t}$, where $\tilde{c}_{i t}=\Delta \log c_{i t}-\Delta \log c_{t}$.

Empirical estimates of the extent of risk sharing are obtained by running a panel regression of idiosyncratic consumption growth on idiosyncratic output growth:

$$
\tilde{c}_{i t}=\alpha_{i}+\beta \tilde{y}_{i t}+\epsilon_{i t}
$$

where $\alpha_{i}$ denote state-specific effects and $\epsilon_{i t}$ is the error term. ${ }^{4}$

If $\beta=0$, the allocation corresponds to what we obtain under complete markets and consumption growth does not respond to output growth. That is, any influences of idiosyncratic movements in output are completely diversified away and we have perfect risk sharing. In contrast, $\beta=1$ indicates no risk sharing at all, since consumption growth perfectly tracks income growth. In this case, agents are not able to smooth consumption at the state-level and we observe a complete lack of risk sharing.

Asdrubali et al. (1996) show that in addition to these two extreme cases, $0<\beta<1$ also provides a quantitative measure of the extent of risk sharing. More specifically, they show that $\beta$ can be interpreted as the fraction of total risk that is not shared across states.

In our empirical analysis, we specify $\beta$ in (1) as:

$$
\beta=\beta_{0}+\beta_{1} x_{i t}
$$

So essentially we augment (1) by adding interaction terms that capture the influence of $\tilde{y}_{i t}$ on $\tilde{c}_{i t}$ via $x_{i t}$. Depending on the precise specification, the interaction variable, $x_{i t}$, will be the share of the married population in the total adult state population. In further specifications we will allow $x_{i t}$ to have a varying impact across different regimes (e.g. divorce law regimes). The coefficient $\beta_{0}$ gives the average exposure to state-specific shocks. What we are primarily interested in is how $x_{i t}$ influences the overall degree of risk sharing as measured by $\beta_{1}$. To avoid

\footnotetext{
${ }^{4}$ Equations similar to (1) have been estimated by Cochrane (1991) and Mace (1991), with micro data and by Lewis (1996), among others, with international data.
} 
potential mis-specifications, we allow $x_{i t}$ to have a direct influence on $\tilde{c}_{i t}$ by adding $x_{i t}$ directly to our estimating equation.

\section{Data}

For our analysis, we use panel data from 1969 through 1990 for all states (excluding Nevada) ${ }^{5}$ and the District of Columbia. We proxy $y_{i t}$ by the gross state product (GSP). Since consumption data are not available, we use state retail sales scaled by the ratio of total private consumption to total US retail sales to proxy for state consumption, $c_{i t}$, as it is standard in the risk sharing literature (see e.g. Asdrubali et al., 1996). Both $y_{i t}$ and $c_{i t}$ are deflated by the index for personal consumption expenditure and in per capita terms. US aggregate output and consumption are calculated as the population weighted averages: $c_{t}=\sum_{i=1}^{50} w_{i} c_{i t}$, and $y_{t}=\sum_{i=1}^{50} w_{i} y_{i t}$ where $w_{i}$ is the population of state $i$ as a proportion of the total US population.

In our analysis, we will employ three different measures for the incidence of marriage, $M_{i t}^{k}$, where $M_{i t}^{k}$ is either the share of married females in the adult female population $(k=f)$, the share of married males in the adult male population $(k=m)$, or an average of both $(k=a)$. Data on the married adult population are not readily available, except for the years in which the decennial US census has been conducted. ${ }^{6}$ We overcome this problem by bringing together data from the decennial US Census from 1960 to 1990, information on the flow into marriage and out of marriage and the age distribution on a state-level. ${ }^{7}$ For each state we take the number of married women in 1960, add the absolute number of marriages and subtract the absolute number of divorces of the years 1961 to 1969. Then we compare the resulting number with the actual number of married women in 1970. In most of the cases the difference between our auxiliary number and the actual number of married women is positive, i.e. the deaths and migration of married women outweigh the immigration of married women. In 17.3 percent of the cases we observe a negative difference, which means that we observe net immigration of married women. Then we assume that the sum of deaths and (im)migration of married women is constant between 1961 and 1969 and distribute the difference over the years 1961 to 1969 equally. An equivalent

\footnotetext{
${ }^{5}$ We disregard Nevada from our analysis since its marriage market seems to be very different compared to the other states. Considering the whole time period, we see that the average marriage rate of Nevada is about fourteen times higher than the average of all other states. Its divorce rate is more than triple of the average over the rest of the US.

${ }^{6}$ In principal the Current Population Survey can be used to construct a proxy of the share of married adult population on a state-level. However 32 states are grouped together between 1968 and 1972 and 38 states cannot be separately identified between 1973 and 1976. In these years, up to five states share the same code.

${ }^{7}$ We have hand-entered the absolute number of marriages and divorces from the annual editions of the Vital Statistics for all the states from 1969 to 1990. The data on the age distribution of the state population are from the Reading Survey of Epidemiology and End Results provided by the National Bureau of Economic Research.
} 
procedure is applied for the 1970s to 1990s and also to obtain a proxy for the number of married men. To obtain the share of married females/males in the total adult state population, we divide the number of married females/males by the number of females/males 15 years of age and older.

The number of married females within a state does not exactly equal the number of married males. This can be explained by different principal residences of spouses, for instance, due to weekly commuting. However, this difference turns out to be rather small. In our sample the difference between the number of married males and married females is on average about 0.1 percent of the total adult population. Note that despite the fact that this difference is small, $M_{i t}^{f}$ and $M_{i t}^{m}$ may differ since the number of females and males (the denominators) do not have to be equal. Thus, we are able to draw some conclusions on gender-specific effects. We also include specifications where we control for the sex-distribution of state $i$.

Over our sample period the American family has undergone some changes: Marriage rates have been falling over the last thirty years. Divorce rates have risen sharply since the mid-1960s, peaked in the early 1980s and have been declining since then (see Figure 1) in the Appendix. This downturn can partly be explained by the decline in the incidence of marriage but is also due to greater marital stability of younger cohorts (Stevenson and Wolfers, 2007a,b). As a result of these developments of flows in and out of marriage we observe a decline in the stock of married people. In 1969 about 64 percent of the adult US population was married; by 1990 this number had fallen to 56 percent. Figure 2 in the Appendix highlights the substantial variation across states.

From all variables we subtract the overall mean since this transformation simplifies the interpretation of coefficients when interaction terms are included. Our method of estimation is ordinary least squares and we calculate robust standard errors - allowing for clustering by states and heteroskedasticity of unknown form - throughout the paper.

\section{Estimation Results}

Our main hypothesis is that married couples are able to share a larger fraction of their idiosyncratic risk. As argued above, via a readier access to credit, marriages may enhance risk sharing not just within states, but also across states. To investigate the role of marriages, we allow $\beta$ in (1) to depend on the share of the married adult population, $M_{i t}^{k}$ :

$$
\beta=\beta_{0}+\beta_{1}^{k} M_{i t}^{k}
$$


where $M_{i t}^{k}$ is either the share of married females, males or an average of both. In each specification we control for state fixed effects, year fixed effects and we include $M_{i t}^{k}$ as a regressor. ${ }^{8}$ If marriages generally improve the interstate allocation of risk, we expect consumption growth to respond less to output growth in states with higher shares of married individuals: $\beta_{1}^{k}<0$.

Table 1: Risk Sharing and Marriages. ${ }^{a}$

\begin{tabular}{|c|c|c|c|c|}
\hline SpeCificAtion & & $\begin{array}{c}(\mathrm{I}) \\
k=a\end{array}$ & $\begin{array}{c}(\mathrm{II}) \\
k=f\end{array}$ & $\begin{array}{c}(\mathrm{III}) \\
k=m\end{array}$ \\
\hline$G S P$ & $\begin{array}{c}0.137^{* * *} \\
(0.037)\end{array}$ & $\begin{array}{c}0.136^{* * *} \\
(0.040)\end{array}$ & $\begin{array}{c}0.163^{* * *} \\
(0.037)\end{array}$ & $\begin{array}{c}0.129 * * * \\
(0.045)\end{array}$ \\
\hline$G S P \cdot M^{k}$ & & $\begin{array}{c}-0.013^{*} \\
(0.007)\end{array}$ & $\begin{array}{c}-0.016^{* * *} \\
(0.006)\end{array}$ & $\begin{array}{l}-0.005 \\
(0.006)\end{array}$ \\
\hline$M^{k}$ & & $\begin{array}{l}-0.095 \\
(0.130)\end{array}$ & $\begin{array}{c}0.045 \\
(0.140)\end{array}$ & $\begin{array}{l}-0.184 \\
(0.110)\end{array}$ \\
\hline Constant & $\begin{array}{c}0.000 \\
(0.006)\end{array}$ & $\begin{array}{c}0.006 \\
(0.009)\end{array}$ & $\begin{array}{c}-0.002 \\
(0.009)\end{array}$ & $\begin{array}{c}0.012 \\
(0.009)\end{array}$ \\
\hline No. of observations & 1,100 & 1,100 & 1,100 & 1,100 \\
\hline R-squared & 0.067 & 0.071 & 0.072 & 0.070 \\
\hline \multicolumn{5}{|c|}{$\begin{array}{l}{ }^{a} \text { The dependent variable is a proxy for state consumption (state retail } \\
\text { sales scaled by the ratio of total private consumption to total US retail } \\
\text { sales). Each specification controls for year fixed effects and state fixed } \\
\text { effects. Estimated using ordinary least squares. Robust standard errors } \\
\text { (allowing for clustering by states and heteroskedasticity of unknown form) } \\
\text { in parentheses below. }{ }^{* *} \text { ) and }{ }^{* * *} \text { indicate statistical significance at the } \\
10 \text {-percent level, } 5 \text {-percent level, and 1-percent level. }\end{array}$} \\
\hline
\end{tabular}

Table 1 shows the estimation results. The first line shows the point estimates of $\beta_{0}$, which is the average exposure to idiosyncratic risk. The baseline specification in the first column indicates that on average, states are able to smooth approximately 86.3 percent of fluctuations in state output. This result is roughly in line, albeit slightly higher than what Asdrubali et al. (1996) report. The remaining columns show the estimation results for the case when $\beta$ depends on the share of married individuals. Regardless of what measure for the share of married population is used, we obtain a negative point estimate for $\beta_{1}$. Therefore, our results suggest that a higher share of married population reduces the exposure to idiosyncratic state income. Considering specification (I), we observe that an increase in the share of married population by one percentage point (sample mean is equal to 58.9 percent) is associated with an increase in risk sharing by 1.3 percentage points. This quantitatively important effect is statistically significant at the 6percent level. Specification (II) employs the share of married females (sample mean is equal to 56.6 percent). In contrast to specification (I) the observed effect is statistically significant at the

\footnotetext{
${ }^{8}$ To conserve space, the results for the state and year fixed effects are not displayed in the tables below, but can be obtained from the authors on request.
} 
1-percent level and quantitatively larger. An increase in the share of married females by one percentage point is associated with an increase in risk sharing by 1.6 percentage points. If we use the fraction of married males (specification (III)) the coefficient is negative, as expected, but not statistically significant at conventional levels. Thus, it appears to be particularly relevant that the share of married females is relatively high.

Although it is hard to pin down why the share of married females is more relevant than the share of males, this result is consistent with microeconomic evidence, documenting that single females are particularly credit-constrained (Ladd, 1982). In fact, the Equal Credit Opportunity Act was amended in response to persistent evidence that single women were discriminated against in the credit market. It is reported that unmarried women were often held to much more rigid credit tests compared to single men (Smith, 1977). Our results suggest that discrimination at an individual level can be discerned at a more aggregate state-level.

Next, we test the sensitivity of our results to a number of alternative specifications. Firstly, we examine the robustness to the sample chosen. To test the importance of the region chosen we skip in turn single states. It turns out that omission of particular states does not influence our results. We also omit in turn single years and find that particular years do not unduly affect our results. ${ }^{9}$

Secondly, we test the robustness of these results to a number of alternative specifications of time, see Table 6 in the Appendix. In the first set of alternative specifications we drop the year fixed effects. Secondly, we include a linear time trend. Then we control for year fixed effects and a linear time trend. Finally, in the last set of specifications we allow for year fixed effects and state-specific linear time trends. In each alternative set of specifications the size of the coefficients and their statistical significance remains basically unchanged.

Thirdly, we add additional population control variables. The literature has documented quite different marriage patterns across black and white citizens (Bennett, Bloom, and Craig, 1989; Brien, 1997; Stevenson and Wolfers, 2007a). Therefore, we have repeated all our sets of alternative specifications from Table 6, however, in addition controlling for the sex-race-distribution of each state-year. In particular, we control for the share of the total population of sex $s$ and of race $r$, where $r$ is white, black and other. ${ }^{10}$ The results in Table 7 in the Appendix show that the quantitative effect as well as the statistical significance of the stock of married population increases slightly when we add these six population control variables.

\footnotetext{
${ }^{9}$ The corresponding estimation output is available upon request.

${ }^{10}$ The data on the sex-race-distribution are based on data from the Reading Survey of Epidemiology and End Results provided by the National Bureau of Economic Research.
} 
Finally, we estimate an errors-in-variables regression (Kmenta, 1997) since we measure the share of the married population with additive noise. Since we do not know the extent of additive noise, we experiment with various values of reliability $\mathcal{R} .{ }^{11}$ Table 8 shows the estimation results for the lowest feasible level of reliability 0.98/0.985. Table 9 assumes a reliability of 0.99 . The results obtained by this alternative method a very similar to our previously reported results.

Overall, the finding that a higher share of married population increases interstate risk sharing is a very robust finding. We will now study this phenomenon in greater detail. In particular, in Section 5.1 we will consider different divorce law regimes and in Section 5.2 we inspect the effect along the business cycle. In our subsequent analysis we will stick to ordinary least squares based on the richest specification (R2-4).

\subsection{The Impact of Divorce Legislation}

The effect of marriages on the availability of bank loans, and thus on the extent of risk sharing across states, depends on the degree of risk sharing within marriages. In reality, the threadpoint of divorce and the fact that intra-marriage transfers cannot be fully legally enforced, may prevent couples from (full) risk sharing. Hence, we generally expect higher levels of risk-sharing if the likelihood of divorce is low. Consequently, we also expect a larger effect of marriages on interstate risk sharing if relationships are stable. In order to observe a variation in the likelihood of divorce and the extent of risk sharing within marriage we exploit quasi-natural experiments provided by the reforms of divorce law. First, we consider the move from mutual consent divorce to unilateral divorce. This reform reduced the cost of divorce and altered marital stability. Second, we explore the impact of laws relating to the division of matrimonial property in divorce. Since the move from common property division to equitable property division makes it easier for banks to assess the net worth of creditors after a potential divorce, we expect more risk sharing under equitable property division. In both cases our identification strategy exploits variation occurring from the different timing of divorce law reforms across US states.

\subsubsection{Unilateral Divorce Law}

The 1970s was a decade of major change in divorce laws that radically altered the parameters of family law (Weitzman, 1985). Most importantly, between 1968 and 1977 the majority of states moved from a divorce law regime which was dominated by mutual consent to so-called unilateral

\footnotetext{
${ }^{11}$ The reliability is defined as, $\mathcal{R}=1-$ (noise variance/total variance), and restricted to be higher than the $\mathrm{R}$-squared from a regression of the variable measured with noise on all other variables, including the dependent variable.
} 
divorce law, see Table 10in the Appendix. Under mutual consent, both spouses had to agree in order to dissolve a marriage legally. Under unilateral divorce, either spouse can file for divorce without the consent of his or her partner. First, Becker, Landes, and Michael (1977) argued that by switching from mutual consent to unilateral divorce one simply transfers the right to divorce (or to remarry) from the spouse who wants to remain married to the partner desiring a divorce. If spouses can bargain efficiently, the Coase Theorem applies and the divorce law reform should only affect the distribution of welfare but should have no effect on the incidence of marriage and divorce. However, there is convincing empirical evidence that divorce does not fit into the paradigm of costless bargaining ${ }^{12}$ and that the move from mutual consent to unilateral divorce laws has affected the incidence of marriage and divorce. ${ }^{13}$

For our purpose, the introduction of unilateral divorce had two important effects: ${ }^{14}$ Firstly, by switching from mutual consent to unilateral divorce law, divorce can be obtained more easily. It has decreased the cost of divorce. As in any setting of risk sharing under incomplete contracts, risk sharing decreases when default is less expensive. Hence, we expect that this incentive effect decreases risk sharing within marriage and therefore also at the interstate-level.

Secondly, analyzing the effects of the unilateral divorce law reform is complicated by a potential selection effect. The change in the cost of divorce may affect the selection into marriage, i. e. it may have changed the composition of the stock of married people. Whether this selection effect increases or decreases the average couples' match quality depends on the underlying theory of marriage. If the primary purpose of marriage is to serve as a signaling device or to realize exogenous benefits, then a reduction in the costs of divorce should lower the match quality of the average couple. In contrast, when marriage serves as a commitment device, a decrease in divorce cost should increase the average match quality (Matouschek and Rasul, 2008).

Empirical evidence shows that the dominant reason to marry is the commitment device, and therefore the move to unilateral divorce law should increase the average couples' match quality (Rasul, 2004; Mechoulan, 2006; Rasul, 2006; Matouschek and Rasul, 2008). The theoretical work

\footnotetext{
${ }^{12}$ Most likely there are transactions costs arising from liquidity constraints and private information. Moreover, in many cases other transaction costs such as legally imposed restrictions and lawyers fees have to expected (Halla, 2007).

${ }^{13}$ There has been a vivid debate in the economics literature whether the move from mutual consent to unilateral divorce laws has caused the large rise in divorce rates (Peters, 1986; Allen, 1992; Peters, 1992; Friedberg, 1998; Wolfers, 2006). The last iteration of this debate has shown that unilateral divorce law led to an immediate spike in the divorce rate that dissipates over time and results in an eventual decline in divorce rates. First the introduction of unilateral divorce caused the divorce of bad matches (initial spike in divorce rate), and, second it has changed the selection into marriage. Couples who would have married under mutual consent did not do so under unilateral divorce (permanent decrease in marriage rates). Bad matches did not marry and we observe a decline in divorce rates (Rasul, 2006; Matouschek and Rasul, 2008).

${ }^{14}$ We follow Matouschek and Rasul (2008) and call these effects incentive effect and selection effect.
} 
by Anderberg (2007) shows that the level of risk-sharing is increasing in the couples' matchquality. In his model the match-quality drives both the risk-sharing decision and the divorce decision. Accordingly, the selection effect of unilateral divorce law should lead to more risk sharing. Thus, these two effects work in opposite directions. Whether the negative incentive effect or the positive selection effect dominates is therefore subject to an empirical verification.

Moreover, banks may have their own valuation of marriages under mutual consent law versus unilateral divorce law. It seems plausible that the incentive effect is more apparent to banks. Therefore, they should value a marriage under mutual consent divorce higher compared to a marriage under unilateral divorce.

To test the role of unilateral divorce law on risk sharing within marriage and its effect on interstate risk sharing we estimate (1) and parameterize $\beta$ as:

$$
\beta=\beta_{0}+\beta_{1} U_{i t} M_{i t}^{k}+\beta_{2}\left(1-U_{i t}\right) M_{i t}^{k}
$$

where $U_{i t}=1$ if state $i$ allows unilateral divorce at time $t$ and $U_{i t}=0$ otherwise. In our sample, 49.8 percent of state-year observations have unilateral divorce laws. The different timing of divorce law reform across US states ensures identification. We control for year fixed effects, state fixed effects, state-specific time trends, the sex-race-distribution and allow for a baseline effect of $M_{i t}^{k}$ and unilateral divorce law on consumption. Table 2 summarizes the results.

Specification(I) shows that under a regime with mutual consent divorce law an increase in the share of married population by one percentage point is associated with an increase in smoothed output by 1.2 percentage points. This quantitatively important effect is statistically significant at the 2-percent level.

Although we obtain an even larger reduction of the exposure of consumption growth to idiosyncratic income growth for the regime with unilateral divorce, the effect is not statistically significant. We interpret this result as an indication that the introduction of unilateral divorce has decreased the risk sharing enhancing effect of marriage.

This result supports the idea that risk sharing under incomplete contracts increases in the cost of default (Ligon, Thomas, and Worrall, 2002) and may reduce the availability of bank loans. The result is also consistent with microeconometric analyses documenting that unilateral divorce law has decreased risk sharing at the individual level: Based on data from the National Health Interview Survey Soloveichik (2007) shows that unilateral divorce has dramatically decreased risk sharing within marriage with respect to health shocks. Similarly, Stevenson (2007) finds 
Table 2: Risk Sharing, Marriages and Unilateral Divorce Law. ${ }^{a}$

\begin{tabular}{|c|c|c|c|}
\hline SPECIFICATION & $\begin{array}{c}(\mathrm{I}) \\
k=a\end{array}$ & $\begin{array}{c}(\mathrm{II}) \\
k=f\end{array}$ & $\begin{array}{c}(\mathrm{III}) \\
k=m\end{array}$ \\
\hline$G S P$ & $\begin{array}{c}0.114^{* * *} \\
(0.039)\end{array}$ & $\begin{array}{c}0.176^{* * *} \\
(0.038)\end{array}$ & $\begin{array}{c}0.114^{* *} \\
(0.048)\end{array}$ \\
\hline$G S P \cdot M^{k} \cdot U$ & $\begin{array}{l}-0.019 \\
(0.012)\end{array}$ & $\begin{array}{c}-0.029^{* *} \\
(0.011)\end{array}$ & $\begin{array}{l}-0.002 \\
(0.007)\end{array}$ \\
\hline$G S P \cdot M^{k} \cdot(1-U)$ & $\begin{array}{c}-0.012^{* *} \\
(0.005)\end{array}$ & $\begin{array}{c}-0.009^{*} \\
(0.005)\end{array}$ & $\begin{array}{c}-0.014^{* *} \\
(0.006)\end{array}$ \\
\hline$M^{k}$ & $\begin{array}{l}-0.129 \\
(0.237)\end{array}$ & $\begin{array}{l}-0.197 \\
(0.253)\end{array}$ & $\begin{array}{l}-0.077 \\
(0.227)\end{array}$ \\
\hline$U$ & $\begin{array}{l}2.537^{*} \\
(1.445)\end{array}$ & $\begin{array}{l}2.798^{*} \\
(1.546)\end{array}$ & $\begin{array}{l}2.332^{*} \\
(1.369)\end{array}$ \\
\hline$(1-U)$ & $\begin{array}{l}2.544^{*} \\
(1.445)\end{array}$ & $\begin{array}{l}2.805^{*} \\
(1.546)\end{array}$ & $\begin{array}{l}2.340^{*} \\
(1.368)\end{array}$ \\
\hline No. of observations & 1,100 & 1,100 & 1,100 \\
\hline R-squared & 0.122 & 0.127 & 0.120 \\
\hline \multicolumn{4}{|c|}{$\begin{array}{l}a \text { The dependent variable is a proxy for state consumption } \\
\text { (state retail sales scaled by the ratio of total private consump- } \\
\text { tion to total US retail sales). Each specification controls for } \\
\text { year fixed effects, state fixed effects, state-specific time trends } \\
\text { and for the share of the total population of sex } s \text { and of race } r \text {, } \\
\text { where } r \text { is white, black and other. Estimated using ordinary } \\
\text { least squares. Robust standard errors (allowing for clustering } \\
\text { by states and heteroskedasticity of unknown form) in paren- } \\
\text { theses below. }{ }^{*}, * * \text { and } * * * \text { indicate statistical significance at } \\
\text { the } 10 \text {-percent level, } 5 \text {-percent level, and 1-percent level. }\end{array}$} \\
\hline
\end{tabular}

evidence that unilateral divorce reduced investment in various types of marriage specific capital such as household specialization, children and spouse's education. Our results show that this reduction in risk sharing also shows up at the state-level and has implications for inter-state risk sharing.

Interestingly, however, specifications (II) and (III) do not show a uniform picture. Specification (II), relying on the share of married females, provides evidence in favor of the selection effect, since the impact of the share of married female population on risk sharing is larger in states that allow for unilateral divorce. This result corroborates empirical evidence indicating that the introduction of unilateral divorce has improved selection into marriage. The shift to, on average, better matched couples has increased risk sharing within marriage which also shows up at the state-level. For Specification (III) we again obtain a dominating incentive effect. That is, the impact of the share of the married male population on risk sharing is larger in states that do not allow for unilateral divorce.

Given that specification(II) and (III) give asymmetric results, our two measures for the extent of marriages do not appear to be substitutes and a sex-specific effect of unilateral divorce 
concerning risk sharing has to be conjectured.

Overall, however, we conclude that with respect to the impact of marriage on inter-state risk sharing the incentive effect dominates the selection effect. Therefore, in sum unilateral divorce has reduced the risk sharing enhancing effect of marriage.

\subsubsection{Matrimonial-Property-Division Laws}

Another important distinction across state divorce laws relates to the division of matrimonial property in divorce. Traditionally, states could be classified as either being in a common property regime or in an equitable property regime. In the former regime, spouses were generally only entitled to assets they themselves brought into marriage, while in the latter, property was generally divided more equally. By the end of the 1970s the majority of US states had moved to divorce regimes with equitable property division, see Table 10in the Appendix. In our sample, 75.7 percent of state-year observations have an equitable property division.

We are now interested in the role of equitable property division on risk sharing within marriage and its effect on interstate risk sharing. Since equitable property division makes it easier for banks to assess the net worth of creditors after a potential divorce, it appears conceivable that banks prefer to lend to married couples under equitable property division. Thus, we expect to see more risk sharing under equitable property division. In contrast to unilateral divorce law, the switch to an equitable property regime had negligible effects on the selection into marriage. Rasul (2004) reports that this law had no effect on first marriages. Only the probability of second marriages went down when property was more equally divided in divorce.

We follow an equivalent empirical strategy as in (4), where we now introduce $E P_{i t}=1$ if state $i$ has equitable property division at time $t$ and $E P_{i t}=0$ otherwise. Again, the different timing of divorce law reforms across US states guarantees identification. The estimation results are summarized in Table 3.

It turns out that the divorce laws relating to the division of matrimonial property in divorce are decisive for the impact of marriages in risk sharing. In state-years with an equitable division of property across spouses in divorce, risk sharing increases with the share of married population. According to specification (I) an increase in the share of married population by one percentage point is associated with a decrease of the exposure to state output by 1.8 percentage points. Based on the share of married females we find a larger effect of 2.1 percentage points. Both estimates are highly statistically significant. If we employ the share of married males we can not identify a statistically significant impact. 
Table 3: Risk Sharing, Marriages and Equitable Property Division. ${ }^{a}$

\begin{tabular}{|c|c|c|c|}
\hline SPECIFICATION & $\begin{array}{c}(\mathrm{I}) \\
k=a\end{array}$ & $\begin{array}{c}(\mathrm{II}) \\
k=f\end{array}$ & $\begin{array}{c}(\mathrm{III}) \\
k=m\end{array}$ \\
\hline$G S P$ & $\begin{array}{c}0.111^{* * *} \\
(0.038)\end{array}$ & $\begin{array}{c}0.158^{* * *} \\
(0.035)\end{array}$ & $\begin{array}{c}0.096^{* *} \\
(0.046)\end{array}$ \\
\hline$G S P \cdot M^{k} \cdot E P$ & $\begin{array}{c}-0.018^{* * *} \\
(0.007)\end{array}$ & $\begin{array}{c}-0.021^{* * *} \\
(0.006)\end{array}$ & $\begin{array}{l}-0.008 \\
(0.007)\end{array}$ \\
\hline$G S P \cdot M^{k} \cdot(1-E P)$ & $\begin{array}{c}0.007 \\
(0.010)\end{array}$ & $\begin{array}{c}0.003 \\
(0.009)\end{array}$ & $\begin{array}{c}0.011 \\
(0.011)\end{array}$ \\
\hline$M^{k}$ & $\begin{array}{l}-0.136 \\
(0.235)\end{array}$ & $\begin{array}{l}-0.183 \\
(0.253)\end{array}$ & $\begin{array}{l}-0.086 \\
(0.223)\end{array}$ \\
\hline$E P$ & $\begin{array}{l}2.602^{*} \\
(1.385)\end{array}$ & $\begin{array}{l}2.799^{*} \\
(1.445)\end{array}$ & $\begin{array}{l}2.409 * \\
(1.341)\end{array}$ \\
\hline$(1-E P)$ & $\begin{array}{l}2.609 * \\
(1.386)\end{array}$ & $\begin{array}{l}2.806^{*} \\
(1.447)\end{array}$ & $\begin{array}{l}2.417^{*} \\
(1.342)\end{array}$ \\
\hline No. of observations & 1,100 & 1,100 & 1,100 \\
\hline R-squared & 0.124 & 0.127 & 0.121 \\
\hline \multicolumn{4}{|c|}{$\begin{array}{l}a \text { The dependent variable is a proxy for state consumption } \\
\text { (state retail sales scaled by the ratio of total private consump- } \\
\text { tion to total US retail sales). Each specification controls for } \\
\text { year fixed effects, state fixed effects, state-specific time trends } \\
\text { and for the share of the total population of sex } s \text { and of race } r \text {, } \\
\text { where } r \text { is white, black and other. Estimated using ordinary } \\
\text { least squares. Robust standard errors (allowing for clustering } \\
\text { by states and heteroskedasticity of unknown form) in paren- } \\
\text { theses below. }{ }^{*}, * * \text { and } * * * \text { indicate statistical significance at } \\
\text { the } 10 \text {-percent level, } 5 \text {-percent level, and } 1 \text {-percent level. }\end{array}$} \\
\hline
\end{tabular}

For the state-years with a common property regime we observe - regardless of the specification - no impact of marriages on risk sharing. This result is plausible, since under a common property regime a divorce restores the distribution of wealth that existed before the marriage.

\subsection{The Role of Marriages over the Business Cycle}

After adverse shocks to state output, households may need to borrow to smooth their consumption. However, if households are subject to credit constraints, borrowing may not be feasible and therefore they may not be able to smooth the impact of the shock. Thus, credit may not be available when it is needed most and consequently, households are particularly exposed to adverse shocks. Since we argue that marriages help to loosen credit constraints, marriages may be particularly relevant for risk sharing during economic downturns.

To test this hypothesis, we define a dummy variable $S C_{i t}=1$ if the growth rate of real GSP in State $i$ is above average and $S C_{i t}=0$ otherwise. Put differently, we interpret periods of below average growth as downturns, where agents would have to borrow in order to sustain a certain 
level of consumption. We let $\beta$ depend on $M_{i t}^{k}$ and $S C_{i t}$ :

$$
\beta=\beta_{0}+\beta_{1} S C_{i t} M_{i t}^{k}+\beta_{2}\left(1-S C_{i t}\right) M_{i t}^{k}
$$

This specification allows the share of the married population to have a different impact on risk sharing in periods of economic up and downturns. If we use the richest set of control variables (year fixed effects, state fixed effects, state-specific time trends, the sex-race-distribution, $M_{i t}^{k}$ and $S C_{i t}$ ), we do not find a statistically significant difference in the impact of marriages over the cycle.

Table 4: Risk Sharing, Marriages and the State Cycle - Alternative Specification. ${ }^{a}$

\begin{tabular}{lccc}
\hline \hline SPECifichtion & $(\mathrm{I})$ & $(\mathrm{II})$ & $(\mathrm{III})$ \\
& $k=a$ & $k=f$ & $k=m$ \\
\cline { 2 - 4 }$G S P$ & 0.088 & $0.124^{* *}$ & 0.084 \\
& $(0.054)$ & $(0.048)$ & $(0.060)$ \\
$G S P \cdot M^{k} \cdot S C$ & -0.005 & -0.005 & -0.002 \\
& $(0.014)$ & $(0.012)$ & $(0.013)$ \\
$G S P \cdot M^{k} \cdot(1-S C)$ & $-0.025^{*}$ & $-0.036^{*}$ & $-0.013^{*}$ \\
& $(0.013)$ & $(0.018)$ & $(0.008)$ \\
$M^{k}$ & -0.111 & 0.018 & -0.191 \\
& $(0.137)$ & $(0.140)$ & $(0.124)$ \\
$S C$ & 0.009 & 0.000 & 0.015 \\
& $(0.009)$ & $(0.009)$ & $(0.009)$ \\
$(1-S C)$ & 0.004 & -0.003 & 0.010 \\
& $(0.010)$ & $(0.010)$ & $(0.009)$ \\
\cline { 2 - 4 } No. of observations & 1,100 & 1,100 & 1,100 \\
R-squared & 0.073 & 0.075 & 0.072 \\
\hline \hline
\end{tabular}

\footnotetext{
${ }^{a}$ The dependent variable is a proxy for state consumption (state retail sales scaled by the ratio of total private consumption to total US retail sales). Each specification controls for year fixed effects and state fixed effects. Estimated using ordinary least squares. Robust standard errors (allowing for clustering by states and heteroskedasticity of unknown form) in parentheses below. *** and *** indicate statistical significance at the 10-percent level, 5-percent level, and 1-percent level.
}

However, Table 4 shows that once we drop state specific time trends, the impact of marriage on risk sharing is statistically and quantitatively more important in periods of economic downturns. We observe that marriages improve risk sharing in all periods - the point estimates are negative throughout. We also see that marriages exert a quantitatively stronger effect on the exposure to state-specific output movements during periods of below average growth. Again, the largest effect is observed if we employ the share of married females. An increase in the share of married female population by one percentage point reduces the exposure to state specific output 
by 3.6 percentage points during an economic downturn. Notably, and in contrast to the results presented above, we now also find significant effects for the share of married male population.

In sum, this suggests that marriages improve risk sharing when it is most needed, namely during economic downturns. However, since this result is - in contrast to the previously reported findings - sensitive to the specification of control variables it has to be interpreted with caution.

\section{Conclusion}

In this paper, we explore the extent to which marriages influence inter-region risk sharing. We find that US states, where the married population represents a higher fraction of the total population, manage to share a larger fraction of their idiosyncratic risks. We draw two broad conclusions from our results: First, even in the US, where highly developed financial markets should be capable of providing substantial risk sharing, informal insurance mechanisms, such as marriages, still play a role. And second, we find that marriages do not only improve risk sharing at the individual level and within states, but also result in a higher degree of risk sharing across states. That is, marriages also help to smooth the impact of state-specific shocks which cannot be smoothed within states.

We find that the design of divorce legislation plays a crucial role. Divorce law does not only determine the cost of divorce but influences many aspects of married life. It sets the parameters for inter-temporal contracting and affects the incentive to invest in marriage-specific capital. This has a bearing on risk sharing behavior within marriage which can also be identified at a more aggregate state-level. The impact of marriage on interstate-risk sharing has decreased due to the adoption of unilateral divorce law and increased because of equitable property division.

We also find some evidence that the impact of marriage on risk sharing is quantitatively more important in periods of economic downturns. This result is consistent with our interpretation that marriage fosters risk sharing by increasing the access to bank credit.

Our results contribute to the discussion on the merits of a high marriage rate. The public and policy makers alike, seem to worry about the decline in marriage. In the US, for instance, a large number of policies have been designed to increase the incidence of marriage and to stabilize existing marriages. ${ }^{15}$ The compelling public interest in keeping the marriage rate high can be explained by a number of reasons: First, it can simply be due to preferences (e.g. ethical

\footnotetext{
${ }^{15}$ These policies comprise large media campaigns, the re-introduction of covenant marriages (Brinig, 1999), and the removal of marriage penalties in tax codes (Alm, Dickert-Conlin, and Whittington, 1999), pension systems (Baker, Hanna, and Kantarevic, 2004) and medicaid programs (Yelowitz, 1998).
} 
and religious beliefs). And, second, it may be based on the empirical evidence highlighting the beneficial effects of marriage, ${ }^{16}$ for which, our paper is a perfect example. We provide evidence for additional welfare benefits associated with marriage, namely a lower exposure to state specific risk.

Although the focus of our paper lies on the risk sharing implications of marriages, the insight that risk sharing at the individual and more aggregated levels interact appears to be rather general. Identifying additional channels through which this interaction may occur seems to be an interesting direction for future research. Finally, we hope to stimulate further research exploring the relationship between family formation, family dissolution and macroeconomic issues.

\section{References}

Allen, D. W., 1992. Marriage and Divorce: Comment. American Economic Review 82 (3), 679685.

Alm, J., Dickert-Conlin, S., Whittington, L. A., 1999. Policy Watch: The Marriage Penalty. Journal of Economic Perspectives 113 (3), 193-204.

Anderberg, D., 2007. Marriage, Divorce and Reciprocity-based Cooperation. Scandinavian Journal of Economics 109 (1), 25-47.

Asdrubali, P., Sørensen, B. E., Yosha, O., 1996. Channels of Interstate Risk Sharing: The United States 1963-1990. Quarterly Journal of Economics 111 (4), 1081-1110.

Azariadis, C., 1975. Implicit Contracts and Underemployment Equilibria. Journal of Political Economy 83 (6), 1183-1202.

Baker, M., Hanna, E., Kantarevic, J., 2004. The Married Widow: Marriage Penalties Matter! $2(4), 634-664$.

Becker, G. S., 1973. A Theory of Marriage: Part I. Journal of Political Economy 81 (4), 813-846.

Becker, G. S., 1974. A Theory of Marriage: Part II. Journal of Political Economy 82 (2), S11S26.

\footnotetext{
${ }^{16}$ An extensive empirical literature, summarized by Waite and Gallagher (2000), has documented a strong correlation between being married and better health, longer life, higher wages, greater wealth and better child outcomes.
} 
Becker, G. S., Landes, E. M., Michael, R. T., 1977. An Economic Analysis of Marital Instability. Journal of Political Economy 85 (6), 1141-1187.

Bennett, N. G., Bloom, D. E., Craig, P. H., 1989. The Divergence of Black and White Marriage Patterns. American Journal of Sociology 95 (3), 692-722.

Blumstein, P., Schwartz, P., 1983. American Couples: Money, Work, Sex. William Morrow and Company, New York, NY.

Boot, A. W. A., 2000. Relationship Banking: What Do We Know? Journal of Financial Intermediation $9(1), 7-25$.

Brien, M. J., 1997. Racial Differences in Marriage and the Role of Marriage Markets. Journal of Human Resources 32 (4), 741-778.

Brinig, M. F., 1999. Economics, Law, and Covenant Marriage. Gender Issues 16 (1-2), 4-33.

Chami, R., Hess, G., 2005. For Better or For Worse? State-Level Marital Formation and Risk Sharing. Review of Economics of the Household 3 (4), 367-385.

Clark, S., 1999. Law, Property, and Marital Dissolution. Economic Journal 109 (454), 41-54.

Cochrane, J. H., 1991. A Simple Test of Consumption Insurance. Journal of Political Economy $99(5), 957-976$.

Demyanyk, Y., Ostergaard, C., Sørensen, B. E., 2007. U.S. john Banking Deregulation, Small Businesses, and Interstate Insurance of Personal Income. Journal of Finance 62 (6), 2763-2801.

Elliehausen, G. E., Lawrence, E. C., 1990. Discrimination in Consumer Lending. Review of Economics and Statistics 72 (1), 156-160.

Friedberg, L., 1998. Did Uniliteral Divorce Raise Divorce Rates? Evidence From Panel Data. American Economic Review 88 (3), 608-627.

Halla, M., 2007. Divorce and the Excess Burden of Lawyers. IZA Discussion Papers 2962, Institute for the Study of Labor (IZA), Bonn.

Hess, G. D., 2004. Marriage and Consumption Insurance: What's Love Got to Do with It? Journal of Political Economy 112 (2), 290-318. 
Hoffmann, M., Shcherbakova, I., 2007. Consumption Risk Sharing over the Business Cycle: The Role of Small Firm's Access to Credit Markets. Unpublished manuscript, University of Zurich.

Hunter, W. C., Walker, M., 1996. The Cultural Affinity Hypothesis and Mortgage Lending Decisions. Journal of Real Estate Finance and Economics 13 (1), 57-70.

Kmenta, J., 1997. Elements of Econometrics, 2nd Edition. University of Michigan Press, Ann Arbor, MI.

Korniotis, G. M., Kumar, A., 2007. Investor Sophistication and Interstate Risk Sharing Using Financial Assets. Unpublished manuscript, University of Texas at Austin.

Kotlikoff, L. J., Spivak, A., 1981. The Family as an Incomplete Annuities Market. Journal of Political Economy 89 (2), 372-391.

Ladd, H. F., 1982. Equal Credit Opportunity: Women and Mortgage Credit. American Economic Review 72 (2), 166-170.

Lewis, K. K., 1996. What Can Explain the Apparent Lack of International Consumption Risk Sharing. Journal of Political Economy 104 (2), 267-297.

Ligon, E., Thomas, J. P., Worrall, T., 2002. Informal Insurance Arrangements with Limited Commitment: Theory and Evidence from Village Economies. Review of Economic Studies 69 (1), 209-44.

Mace, B. J., 1991. Full Insurance in the Presence of Aggregate Uncertainty. Journal of Political Economy 99 (5), 928-956.

Matouschek, N., Rasul, I., 2008. The Economics of the Marriage Contract: Theories and Evidence. Journal of Law and Economics 51 (1), 59-110.

Mechoulan, S., 2006. Divorce Laws and the Structure of the American Family. Journal of Legal Studies 35 (1), 143-174.

Munnell, A. H., Tootell, G. M. B., Browne, L. E., McEneaney, J., 1996. Mortgage Lending in Boston: Interpreting HMDA Data. American Economic Review 86 (1), 25-53.

Peters, E. H., 1986. Marriage and Divorce: Informational Constraints and Private Contracting. American Economic Review 76 (3), 437-454. 
Peters, E. H., 1992. Marriage and Divorce: A Reply. American Economic Review 82 (3), 686-693.

Rasul, I., 2004. The Impact of Divorce Laws on Marriage. Unpublished manuscript, University of Chicago.

Rasul, I., 2006. Marriage Markets and Divorce Laws. Journal of Law, Economics and Organization $22(1), 30-69$.

Rosenzweig, M. R., 1988. Risk, Implicit Contracts and the Family in Rural Areas of Low-Income Countries. Economic Journal 98 (393), 1148-1170.

Rosenzweig, M. R., Stark, O., 1989. Consumption Smoothing, Migration, and Marriage: Evidence from Rural India. Journal of Political Economy 97 (4), 905-926.

Rosenzweig, M. R., Wolpin, K. I., 1985. Specific Experience, Household Structure and Intergenerational Transfers: Farm Family Land and Labor Arrangements in Developing Countries. Quarterly Journal of Economics 100 (Supplement), 961-987.

Rosenzweig, M. R., Wolpin, K. I., 1994. Parental and Public Transfers to Young Women and their Children. American Economic Review 84 (5), 1195-1212.

Smith, J. F., 1977. The Equal Credit Opportunity Act of 1974: A Cost/Benefit Analysis. Journal of Finance 32 (2), 609-622.

Soloveichik, R. H., 2007. In Sickness or in Health? Divorce Law and Health Care Usage. Unpublished manuscript, University of Chicago.

Stevenson, B., 2007. The Impact of Divorce Laws on Marriage-Specific Capital. Journal of Labor Economics 25 (1), 75-94.

Stevenson, B., Wolfers, J., 2007a. Marriage and Divorce: Changes and their Driving Forces. Journal of Economic Perspectives 21 (2), 27-52.

Stevenson, B., Wolfers, J., 2007b. Trends in Marital Stability. Unpublished manuscript, University of Pennsylvania.

Waite, L. J., 1995. Does Marriage Matter? Demography 32 (4), 483-507.

Waite, L. J., Gallagher, M., 2000. The Case for Marriage: Why Married People Are Happier, Healthier, and Better Off Financially. Broadway, New York, NY. 
Weiss, Y., 1993. The Formation and Dissolution of Families: Why Marry? Who Marries Whom? and What Happens Upon Marriage and Divorce. In: anb Oded Stark, M. R. R. (Ed.), Handbook of Population and Family Economics. Vol. 1A. Elsevier, Ch. 3, pp. 81-123.

Weitzman, L. J., 1985. The Divorce Revolution: The Unexpected Social and Economic Consequences for Women and Children in America. Free Press, New York.

Wolfers, J., 2006. Did Uniliteral Divorce Laws Raise Divorce Rates? A Reconciliation and New Results. American Economic Review 96 (5), 1802-1820.

Yelowitz, A. S., 1998. Will Extending Medicaid to Two-Parent Families Encourage Marriage? Journal of Human Resources 33 (4), 833-865. 
$7 \quad$ Appendix

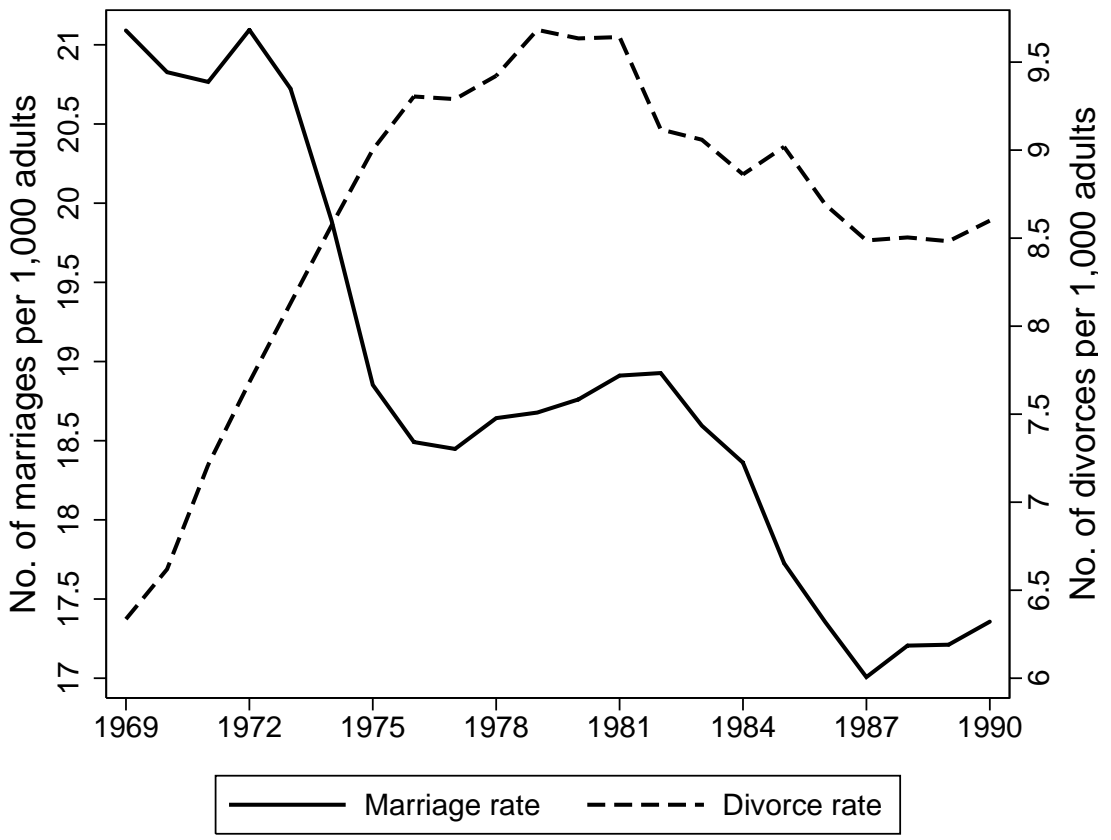

Figure 1: Marriage and Divorce Rate, United States 1969-1990.

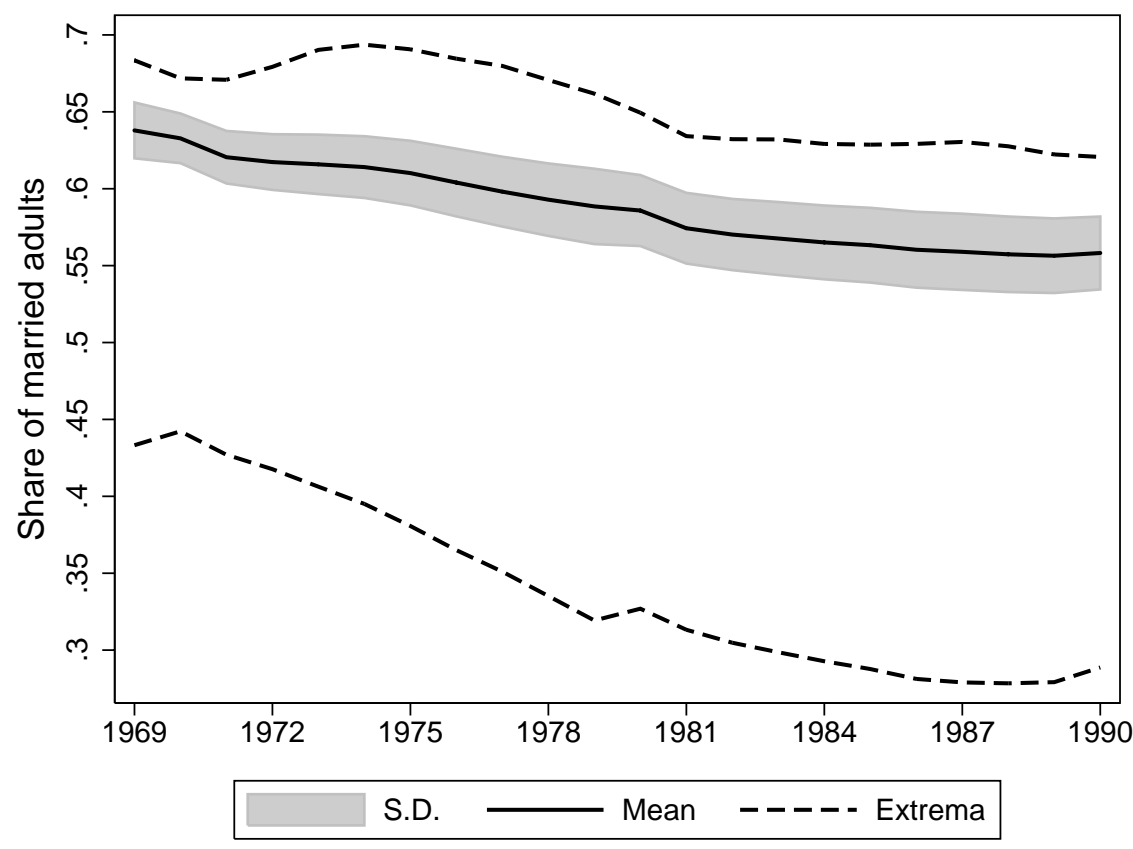

Figure 2: Share of Married Adult Population, United States 1969-1990. 
Table 5: Probit Estimation of Mortgage Acceptance. ${ }^{a}$

\begin{tabular}{lcc}
\hline & MFX & S.E \\
\cline { 2 - 3 } Married & $0.045^{* * *}$ & $(0.017)$ \\
White & $0.102^{* * *}$ & $(0.024)$ \\
Male & -0.006 & $(0.017)$ \\
Education & 0.001 & $(0.016)$ \\
Number of dependents & -0.007 & $(0.006)$ \\
Self-employed & $-0.053^{* *}$ & $(0.024)$ \\
Unemployed & -0.005 & $(0.003)$ \\
Co-signer of application & 0.016 & $(0.035)$ \\
HRAT & 0.001 & $(0.001)$ \\
OBRAT & $-0.004^{* * *}$ & $(0.001)$ \\
MHIST & 0.077 & $(0.084)$ \\
PUB & $-0.185^{* * *}$ & $(0.040)$ \\
CHIST & $0.120^{* * *}$ & $(0.024)$ \\
MULTI & $-0.047^{*}$ & $(0.027)$ \\
LNPR & $-0.156^{* * *}$ & $(0.038)$ \\
THK & -0.004 & $(0.020)$ \\
LOC & $-0.032^{* *}$ & $(0.014)$ \\
\cline { 2 - 3 } No. of observations & \multicolumn{2}{c}{1,961} \\
Log-likelihood intercept only: & \multicolumn{2}{c}{-732.742} \\
Log-likelihood full model & \multicolumn{2}{c}{0.191} \\
McFadden's Pseudo R-squared & \multicolumn{2}{c}{. } \\
\hline \hline
\end{tabular}

${ }^{a}$ Data used is from Hunter and Walker (1996). The dependent variable is equal to one if mortgage was accepted and zero otherwise. HRAT is the ratio of monthly housing expenses to monthly income. OBRAT is the ratio of total monthly obligations to monthly income. MHIST is equal to one if two or fewer mortgage payments are recorded as late, and zero otherwise. PUB is equal to one if there are public record default, and zero otherwise. CHIST is equal to one if there is no history of delinquent credits (defined as one or more accounts 60 days or more past due), and zero otherwise. MULTI is equal to one if applicant is purchasing a two- to four-family house, and zero otherwise. LNPR is the Loan-to-price ratio. THK is equal to one if there more than two credit reports in the file, and zero otherwise. LOC is equal to one if tract vacancy is less than the MSA median, and zero otherwise. Estimated using probit model. *, ** and ${ }^{* * *}$ indicate statistical significance at the 10-percent level, 5-percent level, and 1-percent level. The marginal effect is the change in the probability of mortgage acceptance caused by an infinitesimal change of each independent continuous variable or, the discrete change in the probability for a changing binary variable with all the other variables fixed at their means. 


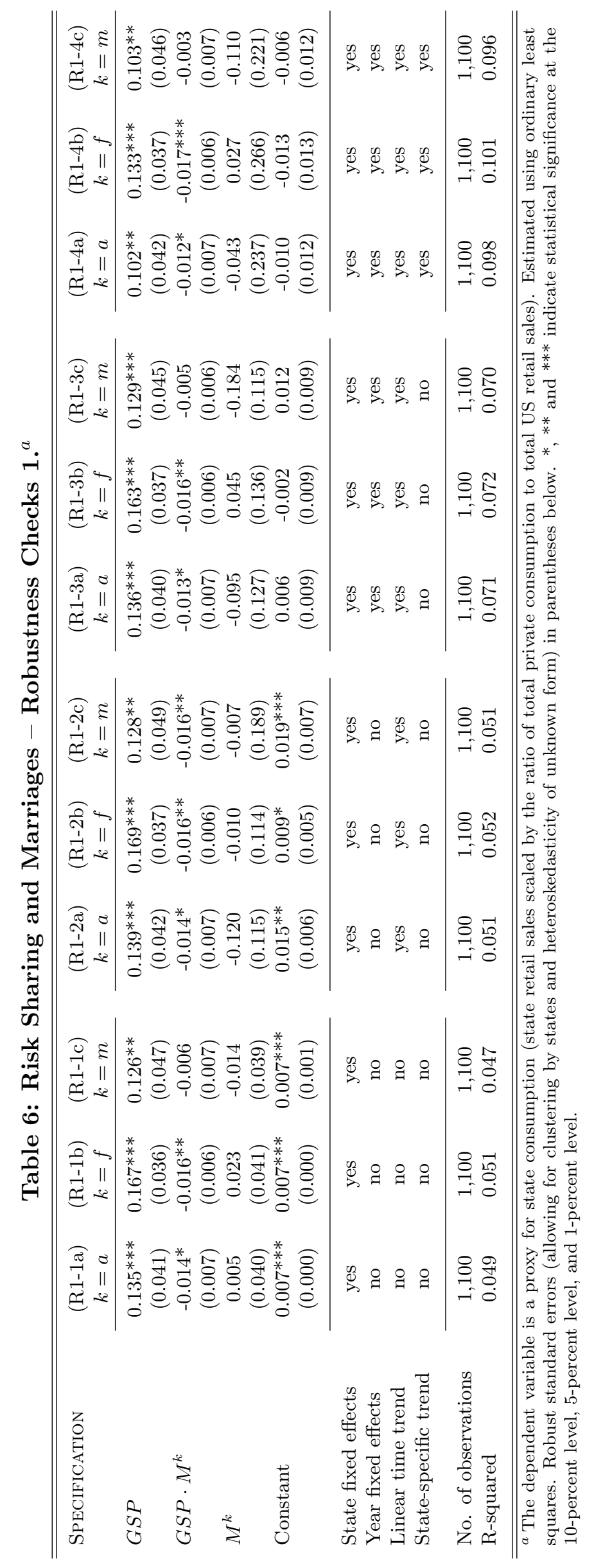




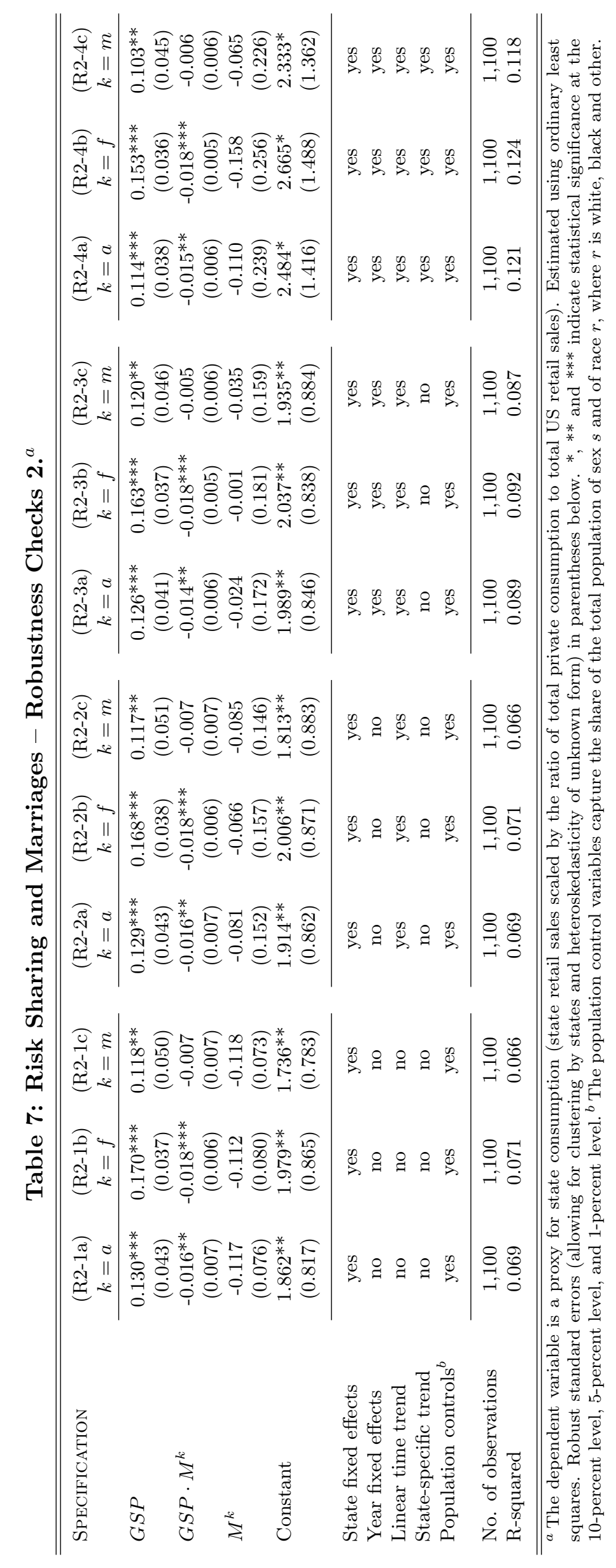




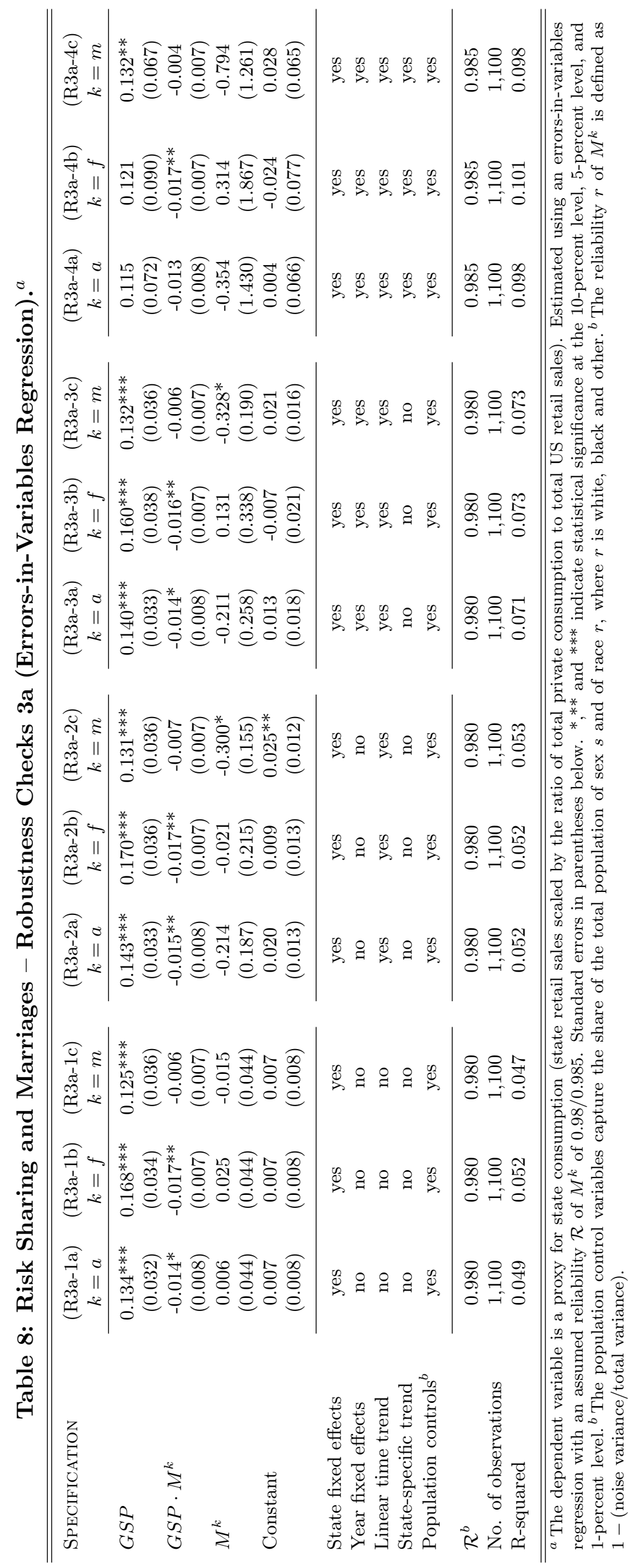




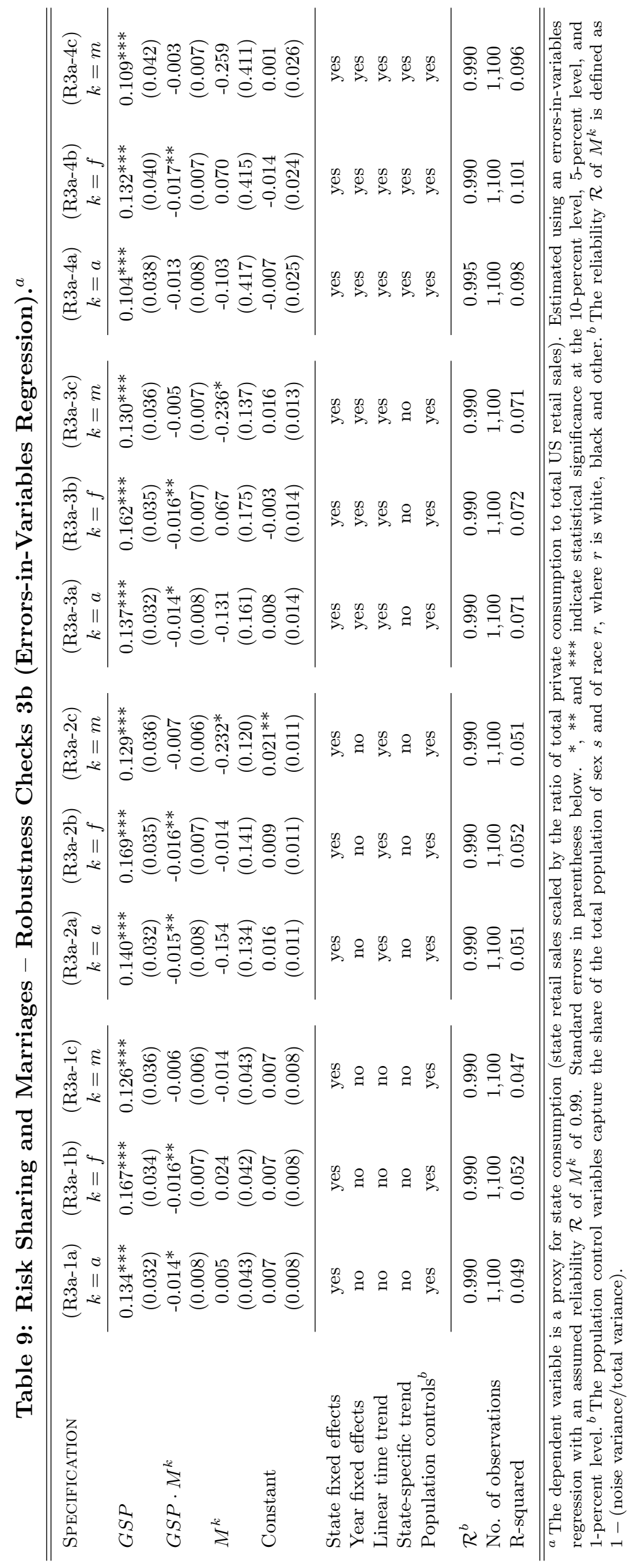


Table 10: Divorce Law Across the United States. ${ }^{a}$

\begin{tabular}{|c|c|c|}
\hline & \multicolumn{2}{|c|}{ Year of Enactment of } \\
\hline & Unilateral Divorce & Equitable Division \\
\hline Alabama & 1971 & 1980 \\
\hline Alaska & 1935 & prior 1950 \\
\hline Arkansas & - & 1979 \\
\hline Arizona & 1973 & prior 1950 \\
\hline California & 1970 & prior 1950 \\
\hline Colorado & 1971 & 1972 \\
\hline Connecticut & 1973 & 1973 \\
\hline District of Columbia & - & 1977 \\
\hline Delaware & - & prior 1950 \\
\hline Florida & 1971 & 1988 \\
\hline Georgia & 1973 & 1980 \\
\hline Hawaii & 1973 & 1955 \\
\hline Idaho & 1971 & 1958 \\
\hline Illinois & - & 1977 \\
\hline Indiana & 1973 & 1973 \\
\hline Iowa & 1970 & prior 1950 \\
\hline Kansas & 1969 & prior 1950 \\
\hline Kentucky & 1972 & 1972 \\
\hline Louisiana & - & 1978 \\
\hline Maine & 1973 & 1973 \\
\hline Maryland & - & 1969 \\
\hline Massachusetts & 1975 & 1974 \\
\hline Michigan & 1972 & 1983 \\
\hline Minnesota & 1974 & 1951 \\
\hline Mississippi & - & prior 1950 \\
\hline Missouri & - & 1974 \\
\hline Montana & 1975 & 1976 \\
\hline North Carolina & - & 1981 \\
\hline North Dakota & 1971 & prior 1950 \\
\hline Nebraska & 1972 & 1972 \\
\hline New Hampshire & 1971 & 1988 \\
\hline New Jersey & - & 1971 \\
\hline New Mexico & 1973 & prior 1950 \\
\hline Nevada & 1973 & prior 1950 \\
\hline New York & - & 1962 \\
\hline Ohio & - & 1990 \\
\hline Oklahoma & 1953 & 1975 \\
\hline Oregon & 1973 & 1971 \\
\hline Pennsylvania & - & 1979 \\
\hline Rhode Island & 1976 & 1979 \\
\hline South Carolina & - & 1979 \\
\hline South Dakota & 1985 & prior 1950 \\
\hline Tennessee & - & 1959 \\
\hline Texas & 1974 & 1970 \\
\hline Utah & - & prior 1950 \\
\hline Virginia & - & 1982 \\
\hline Vermont & - & prior 1950 \\
\hline Washington & 1973 & 1978 \\
\hline Wisconsin & - & 1978 \\
\hline West Virginia & - & 1984 \\
\hline Wyoming & 1977 & prior 1950 \\
\hline
\end{tabular}

${ }^{a}$ The coding for unilateral divorce law follows Wolfers (2006) and the coding for equitable property division is based on Rasul (2004). 